\title{
UTILIZATION OF SWEETPOTATO BASED CONFECTION TECHNOLOGY: A PANACEA TO FOOD CRISIS AMONG WOMEN FARMERS IN IMO STATE
}

\author{
*AMAMGBO, L. E. F., *AKINPELU, A. O. AND **EKUMANKAMA, O.O. \\ *National Root Crops Research Institute, Umudike, P.M.B. 7006, Umuahia, Abia State \\ **Department of Agricultural Extension and Rural Sociology, Michael Okpara \\ University of Agriculture, Umudike, Abia State. \\ Corresponding author's Email: lefamangbo@yahoo.com
}

\begin{abstract}
Utilization of sweet potato-based confectionary was used as a step to reducing food crisis among women farmers in Imo state because of the health benefits, environmental friendliness and ability to make a home food secured with little investments. This is because such technology will help serve as an avenue to reduce food crisis among women. The study identified the demographic characteristics of the women farmers, level of awareness of the technology, level of utilization and constraints associated with utilization of the technology. One hundred and twenty women farmers were sampled in the study area using multi-stage random sampling technique. The study revealed that lack of credit, contact with extension agents and membership of cooperative societies were problems associated with utilization of the technology.
\end{abstract}

Key words: Transfer and utilization, Panacea, Food crisis, Sweet potato based confectionaries.

\section{INTRODUCTION}

Evidence abound that root and tuber crops are efficient sources of low-cost calories because of their adaptability to wide range of ecologies. Similarly, the rural poor in some African countries (Aliyu, 2000), Nigeria inclusive obtain about $65-75 \%$ of their daily food energy from root and tuber crops. Alexandratos, (1995) Scott et al., (2000) and (Chandara, 2003), described root and tuber crops as crops that deserve particular attention because many developing world's poorest and most food insecure households including Nigeria look at these crops as a contributing, if not the principal source of food, nutrition and income. Root and tuber crops mean many things to different people. For some, it means the difference between subsistence and achieving a leg on the economic ladder, to others they mean the difference between survival and starvation (Scott et al., 2000).

Sweet potato, the $4^{\text {th }}$ major root crop in Nigeria, $7^{\text {th }}$ most important food crop worldwide has diverse range of positive attributes: it could be grown three times a year, has high yield potential, high nutritional value, resistance to production stress, environmentally friendly and diverse food form among others. (Ikwelle, et al., 2001 and Kays, 2004). Sweet potato, if properly harnessed can play a major role in poverty reduction, food security and improved health situation.

Food security is a situation in which all people at all times have physical and economic access to sufficient safe and nutritious food to meet their dietary needs and food preference for active healthy living (IFPRI, 1997). From the above, food crisis is termed opposite of food insecurity. The sharp increase in food prices over the years has raised serious concern about the food and nutrition situation of poor people in developing countries. Ensuring therefore that all Nigerians have enough food for healthy and productive life became a fundamental challenge to the government of Nigeria (Unamma, 2001). According to Braun, 2008, nearly every agricultural commodity is part of this rising price trend. He further opined that since 2003, world maize and wheat have more than doubled the price, rice 
has jumped to unprecedented levels, dairy products, meat, poultry and palm oil have experienced hikes. Root and tuber crops are not exceptional in this scenario. This has serious consequences for the purchasing power of the poor who are mostly women.

Women are often constrained in access to and control of land, water, and other natural resources (IFPRI, 2008). Their contribution in agricultural business and other sphere of community development attracted inadequate recognition. Empirical reports revealed that women farmers play vital role in food production, processing and marketing in Nigeria (Rahman et al., 2004). To this end, the value addition on sweet potato and other root and tuber crops promoted introduction of confectioneries. This study investigated the transfer and utilization of sweet potato based confectionary among women in Imo State. Specifically the study: identified the demographic characteristics of farmers in the study area; determined level of awareness of the technology; determined level of utilization; identified constraints of the technology utilization

\section{RESEARCH METHODOLOGY}

The study was conducted in Imo state. Imo state is located in the south-east agro ecological zone of Nigeria. Imo state has a population of 3,723,756 and covers an area of 5,288 square kilometers (NBS, 2006). The state comprises of 21 LGAs and has 3 agricultural zones - Okigwe, Orlu and Owerri. This state lies within the tropical rain forest zone with luxuriant growth of trees in the south. A wide range of food crops cultivated in Imo state include: sweet potato, cassava, yam, maize, melon, vegetable, rice, etc. The state was purposively selected because the sweet potato based confectionary technology has since been transferred to women farmers in the state (Unamma, 2001).A multi-stage random sampling technique was adopted. Two agricultural zones were randomly selected from the state (Owerri and Okigwe) and six blocks were randomly selected from each zone where ten respondents were randomly selected given a sample size of 120 respondents. Descriptive statistics (means, frequency, percentages) was used to analyze the data.

\section{RESULTS AND DISCUSSION}

This study examined the demographic characteristics of the women farmers using age, marital status, educational background/level, household size, occupation, farming experience, level of sweet potato production, knowledge of sweet potato flour processing, and steps in sweet potato flour processing. Majority of the women farmers $(33.75 \%)$ were in the age range of 41-50 years as indicated in table 1 . The average age of the farmers was 40 years. It agrees with Adegbite et al., (2007), who identified man age of women farmers to be 41 years. He went further to indicate that these groups of women farmers are gradually moving out of active work force and hence the sweet potato based confectionaries is a viable technology for this group to remain in farming. Majority of the respondents $(51.50 \%)$ were married while $35.35 \%$ were single and $13.15 \%$ were either divorced or widowed. Most of the women farmers have higher education as indicated by $34.2 \%$ of the respondents. This was followed by respondents who completed primary school $(23.15 \%)$. Apart from making farming the primary occupation $(45.55 \%)$ the women also engaged in other secondary occupation like civil service $(25.45 \%)$, artisan $(14.00 \%)$ and trading $(7.20 \%)$. Most of the respondents $(62.35 \%)$ have a household size of 5-8 members. The study equally revealed that $87.05 \%$ of the women just have between 1-5 years experience of the technology.

Table 1 also revealed that about $51.3 \%$ of the women were not able to list the steps in processing sweet potato into flour which presupposes that awareness was low. The women mostly processed sweet potato into flour to generate income as indicated by $39.9 \%$. Also, the study revealed that $58.05 \%$ of the women produce between 1-5 bags of sweet potato. Utilization was of medium level where three out of the five products were produced. The 
study equally revealed that lack of credit facility was very serious problem, extension contact with the women was not a serious problem and not being a member of any cooperative organization was serious but not very serious as shown in table 2.

\section{CONCLUSION AND RECOMMENDATIONS}

The focus on sweet potato-based confectionary as a panacea to food crisis among women farmers in Imo state is a step in the right direction. The identified age groups involved in sweet potato-based confectionary are gradually moving out of productive and active working age, and there was need to save for a less labourious but more competing small-scale business to secure their livelihood in future, alleviate poverty and avert food crisis. It could be concluded that provision of credit facilities, efficient extension agents participation and membership of cooperative societies would go a long way in encouraging women farmers in the study area to adopt the technology and thus reducing the incidence of food crisis.

\section{REFERENCES}

Adegbite, A. M.; Momoh, D. A. and Alalade, A. (2007). Determinants of Informal Savings Mobilization among Farmers in Ogun State. Nigeria. Journal of Sustainbale Development. (4) $1 \& 2: 25-31$.

Alexandratos, N. (1995) World Agriculture: Towards 2010. An FAO Study New York FAO and John and Sons.

Aliyu, A. (2000). Strategies for National Food Security through Root and Tuber Crops Research and Production. Paper Presented at the Annual Review and Research Planning Workshop at National Root Crops Research Institute, Umudike held between March $8^{\text {th }}-12^{\text {th }}$

Braun, Joachim Von (2008). Rising Food Prices: What should be done? IFPRI Policy Report, Nigeria.

Chandara S. (2003). Tropical Root Crops Opportunity for Poverty Alleviation through sustainable Development Book of Abstract for the $13^{\text {th }}$ symposium of ISTRC held in Arusha, Tanzania November $10^{\text {th }}-14^{\text {th }}$.

IFPRI (2008). Promising Approaches to Address the Needs of Poor Female Farmers. IFPRI Note $13: 1-8$

IFPRI (1997). Achieving Food Security in Southern Africa: New Challenges, New Opportunities (Eds) Lawrence Haddad : 3

Ikwelle, M.C., Ezulike, T.O. and Eke-Okoro O.N. (2001). Contribution of Root an Tuber Crops to the Nigerian Economy. Proceedings of $8^{\text {th }}$ International Society for Tropical Root Crops - Africa Branch (ISTRC-AB) : $13-18$

Kays, S. J. (2004). "Sweet Potato Production Worldwide Assessment, Trends and the Future http//www.actahotorg/members/showpdf?booknrarni=6702. (October 2006).

National Bureau of Statistics (2006). Annual Abstract of Statistics: 2- 24

Rahman, S. A. and Usman, J. I. (2004). Comparative Analysis of Women Participation in Agricultural Production in Northern and Southern Kaduna State, Nigeria. In Agbede, O. O.; Idris, M. B.; Rahman, S. A.; Ari, M. A.; Ogara, I. M. Asumugha, G. N. (eds) Mobilizing Investors for Sustainable Agricultural Research, Development and Production in Nigeria. Proceedings of the $38^{\text {th }}$ Annual Conference of the Agricultural Society of Nigeria, held at College of Agriculture, Lafia, Nassarawa State, Nigeria, October 17-21, pp 388-389.

Scott, G.J., M.W. Rosegrant and C. Ringler (2000). Root and tubers for the $21^{\text {st }}$ century. 
Trends, Projections and Policy options. Food and Agriculture and the environment Discussion 31. Washington DC: International Food Policy Research Institute (IFPRI) and International Potato Centre (CIP).

Unamma, R.P.A. (2001). Agricultural Technology Generation and Transfer Strategies for food securities. Invited keynote address at $16^{\text {th }}$ Annual Zonal REFILS Workshop,

Umudike. Proceedings of the $16^{\text {th }}$ Annual Zonal Research Extension Farmers Inputs Linkage Systems (REFILS) Workshop South-East/South-South Zones of Nigeria. : 4

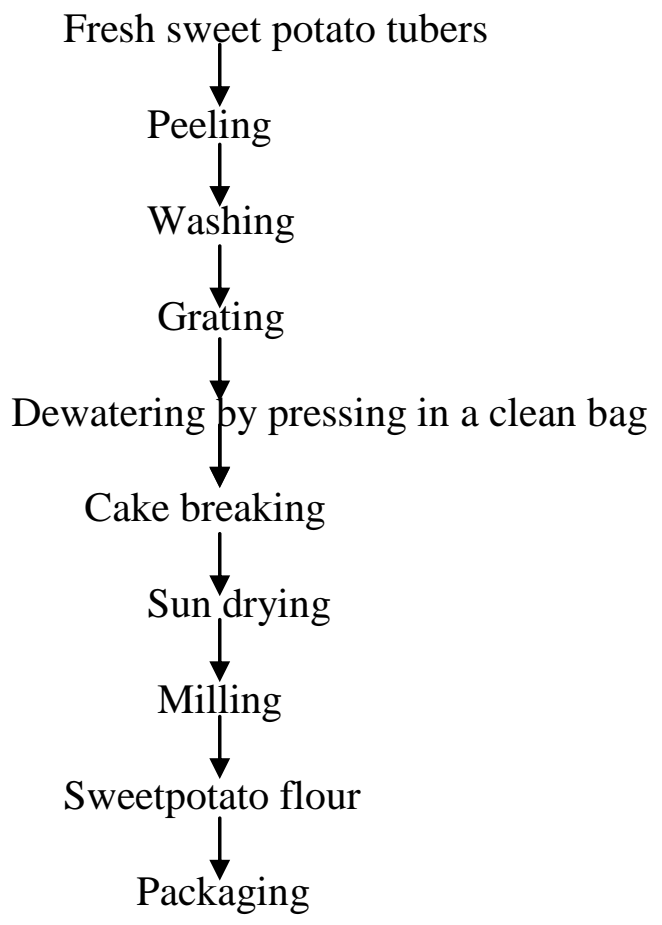

Fig. 1: Flow chart (Production of Sweet potato Flour)

Table 1: Percentage Distribution of End-Users by Demographic Characteristics.

\begin{tabular}{llll}
\hline Age & Owerri & Okigwe & Mean \\
\hline $1-30$ & 6.6 & 9.1 & 7.85 \\
$31-40$ & 27.8 & 7.3 & 17.55 \\
$41-50$ & 31.2 & 36.3 & 33.75 \\
$51-60$ & 22.9 & 23.7 & 23.3 \\
Above 60 & 11.5 & 23.6 & 17.55 \\
Mean age 40 years & & & \\
\hline Total & $\mathbf{1 0 0 . 0}$ & $\mathbf{1 0 0 . 0}$ & \\
Marital Status & & & \\
Married & 88.5 & 14.5 & 51.5 \\
Single & 3.3 & 67.4 & 35.35 \\
Divorcee & 6.6 & 14.5 & 10.55 \\
Widowed & 1.6 & 3.6 & 2.6 \\
\hline Total & $\mathbf{1 0 0 . 0}$ & $\mathbf{1 0 0 . 0}$ & \\
\hline
\end{tabular}


Journal of Agriculture and Social Research (JASR) VOL. 10, No. 1, 2010

\begin{tabular}{|c|c|c|c|}
\hline \multicolumn{4}{|l|}{ Educational Level } \\
\hline No formal education & 1.6 & 1.8 & 1.7 \\
\hline Adult education & 16.4 & 1.8 & 9.1 \\
\hline Primary $\quad$ School & 6.6 & 9.1 & 7.85 \\
\hline \multicolumn{4}{|l|}{ Incomplete. } \\
\hline Primary complete & 23.0 & 23.6 & 23.3 \\
\hline JSS & 3.3 & 1.8 & 2.55 \\
\hline Higher Education & 37.5 & 30.9 & 34.2 \\
\hline Total & 100.0 & 100.0 & \\
\hline \multicolumn{4}{|l|}{ Household Size } \\
\hline $1-4$ & 19.7 & 39.2 & 29.45 \\
\hline $5-8$ & 73.7 & 51.0 & 62.35 \\
\hline $9-12$ & 6.6 & 9.8 & 8.2 \\
\hline \multicolumn{4}{|c|}{ Years of Experience in Sweet potato Flour Production } \\
\hline $1-5$ & & 97.7 & 76.4 \\
\hline $5-10$ & & 2.1 & 10.9 \\
\hline $11-15$ & & - & 10.9 \\
\hline Above 15 & & - & 1.8 \\
\hline Total & & 100.0 & 100.0 \\
\hline \multicolumn{4}{|c|}{ Level of Sweet potato Production } \\
\hline $1-5$ bags & & 43.3 & 72.8 \\
\hline $5-10$ & & 56.7 & 27.3 \\
\hline $11-15$ & & - & - \\
\hline Above 15 & & - & - \\
\hline Total & & 100.0 & 100.0 \\
\hline \multicolumn{4}{|l|}{ Primary Occupation } \\
\hline Civil servant & & 25.4 & 25.5 \\
\hline Farming & & 47.5 & 43.6 \\
\hline Trading & & 1.7 & 12.7 \\
\hline Artisan & & 15.3 & 12.7 \\
\hline Others & & 10.2 & 5.5 \\
\hline Total & & 100.0 & 100.0 \\
\hline
\end{tabular}

Source: Field Survey 2008 
Journal of Agriculture and Social Research (JASR) VOL. 10, No. 1, 2010

Table 2: Percentage Distribution of respondents according to number of Sweet potatobased Confectionaries Produced

\begin{tabular}{|c|c|c|c|c|c|c|c|}
\hline & \multicolumn{5}{|c|}{ Number of confection } & \multirow{2}{*}{$\begin{array}{l}\text { Mean/ra } \\
\text { tio of } \\
\text { utilizati } \\
\text { on }\end{array}$} & \multirow{2}{*}{$\begin{array}{l}\text { Level of } \\
\text { utilizati } \\
\text { on }\end{array}$} \\
\hline Zones & Cake & $\begin{array}{l}\text { Meat } \\
\text { pie }\end{array}$ & $\begin{array}{l}\text { Dough } \\
\text { nut }\end{array}$ & $\begin{array}{l}\text { Biscu } \\
\text { it }\end{array}$ & $\begin{array}{l}\text { Chin- } \\
\text { chin }\end{array}$ & & \\
\hline Owerri & - & (15) & $\begin{array}{l}16 \\
(26.67)\end{array}$ & - & $\begin{array}{l}16 \\
(26.67)\end{array}$ & 3.5 & high \\
\hline Okigwe & $\begin{array}{l}10 \\
(16.6 \\
7)\end{array}$ & $\begin{array}{l}11 \\
(18.33)\end{array}$ & $\begin{array}{l}10 \\
(16.67)\end{array}$ & $\begin{array}{l}6 \\
(10)\end{array}$ & $\begin{array}{l}8 \\
(13.33)\end{array}$ & 2.1 & med \\
\hline
\end{tabular}

Source: Field survey 2008

Figures in parenthesis represent percentage

Distribution of respondents according to problem associated with utilization

\begin{tabular}{|c|c|c|c|c|c|c|}
\hline \multirow[t]{2}{*}{ Problems } & \multicolumn{2}{|c|}{ Very serious } & \multicolumn{2}{|l|}{ Serious } & \multicolumn{2}{|c|}{ Not Serious } \\
\hline & Frequency & $\begin{array}{l}\text { Percenta } \\
\text { ge }\end{array}$ & $\begin{array}{l}\text { Frequen } \\
\text { cy }\end{array}$ & $\begin{array}{l}\text { Percenta } \\
\text { ge }\end{array}$ & $\begin{array}{l}\text { Frequen } \\
\text { cy }\end{array}$ & $\begin{array}{l}\text { Percen } \\
\text { tage }\end{array}$ \\
\hline $\begin{array}{l}\text { Lack of } \\
\text { credit facility }\end{array}$ & 106 & 88.4 & 10 & 8.3 & 4 & 3.3 \\
\hline $\begin{array}{l}\text { Extension } \\
\text { contact }\end{array}$ & 55 & 45.8 & 61 & 51 & 4 & 3.3 \\
\hline $\begin{array}{l}\text { Non } \\
\text { membership } \\
\text { of } \\
\text { cooperatives }\end{array}$ & & & & & 33 & 27.3 \\
\hline
\end{tabular}

Source: Field Survey 2008 